\title{
Accountantskosten in de jaarrekening van beursgenoteerde ondernemingen
}

\section{Dick van Offeren, Tim Verdoes en Joop Witjes}

SAMENVATTING Sinds medio 2008 is het wettelijk verplicht de accountantskosten in de jaarrekening te vermelden. Deze verplichting vindt zijn oorsprong in de Europese richtlijn, die de transparantie van de onafhankelijkheid van de accountantsorganisatie bevordert. Transparantie van de onafhankelijkheid van accountantsorganisatie en vermelding van accountantskosten in de jaarrekening hebben een hybride regeling tot gevolg. Het desbetreffende wetsartikel heeft vragen opgeworpen over de uitvoering. Wij geven hiervan een kort overzicht. Tevens bespreken wij de uitkomsten van een inventariserend jaarrekeningenonderzoek dat de vraag beantwoordt hoe beursgenoteerde ondernemingen in de jaarrekening 2008 zijn omgegaan met deze nieuwe wettelijke verplichting. Uit de kwantitatieve analyse blijkt dat voor de beursgenoteerde ondernemingen in Nederland sprake is van drie dominante accountantsorganisaties. Voorts is vastgesteld dat de verslaggevingspraktijk oplossingen heeft gevonden voor de vermelding van de accountantskosten. Verder hebben wij de kwantitatieve betekenis van de accountantskosten naar verschillende gezichtspunten in kaart gebracht. De besproken literatuur geeft uitdagende onderzoeksgebieden aan waarvoor accountantshonoraria worden gebruikt. Eerdere onderzoekers hebben deze gegevens met vragenlijsten verzameld. Nu kunnen ze aan de jaarrekening worden ontleend. Dit heeft ten minste twee voordelen. In de eerste plaats is er geen non-respons bias. In de tweede plaats is de betrouwbaarheid van de gegevens verhoogd, omdat de gepubliceerde gegevens door accountants zijn gecontroleerd. Een beperking die uit het onderzoek blijkt, is dat de informatieverstrekking nog onvoldoende vergelijkbaar is.

RELEVANTIE VOOR DE PRAKTIJK Opstellers, gebruikers en controleurs van jaarrekeningen zijn geconfronteerd met de nieuwe wettelijke eis om de accountantskosten in de toelichting op te nemen. Dit artikel laat zien op welke wijze de verslaggevingspraktijk invulling geeft aan deze disclosure-eis en hoe de accountantskosten naar verschillende invalshoeken zijn verdeeld.

\section{Inleiding}

Op 27 juni 2008 is de Wet wijziging van de wet toezicht accountantsorganisaties (Wta) en Boek 2 van het Burgerlijk wetboek, in werking getreden (wet van 12 juni 2008). Voor jaarrekeningen die na 27 juni 2008 zijn opgemaakt, bete- kent dit dat ondernemingen die onder verplichte accountantscontrole vallen informatie over de honoraria van de accountantsorganisatie in de toelichting dienen op te nemen. Het is voor het vervolg van het betoog van belang dat het hier gaat om twee aspecten. Het eerste aspect is de wijziging van de Wta, het tweede de daaraan gekoppelde wijziging van Boek $2 \mathrm{BW}$, in casu de introductie van artikel 2:382a BW. Deze twee aspecten veroorzaken naar onze mening hybride wetgeving.

De vermelding van de accountantskosten vloeit voort uit implementatie in de Nederlandse wetgeving van EU Richtlijn 2006/43/EG. Openbaarmaking van de honoraria is één van de veiligheidsmaatregelen die kunnen worden genomen om de bedreiging van de onafhankelijkheid van de accountant af te zwakken of weg te nemen. Andere veiligheidsmaatregelen zijn verboden, beperkingen en andere beleids- en proceduremaatregelen ter regulering van het accountantsberoep.

Naar aanleiding van de introductie van dit wetsartikel zijn in verschillende media vragen gerezen over de reikwijdte en toepassing. In dit artikel onderzoeken wij welke oplossingen de verslaggevingspraktijk voor deze vragen heeft gevonden. Daartoe bespreken wij eerst de totstandkoming van het wetsartikel, daarna de opgeworpen vragen en de praktische toepassing. Bij de praktische toepassing besteden wij aandacht aan de kwantitatieve vermeldingen van de accountantskosten in de jaarrekening. Deze openbaarmaking biedt uitdagingen voor wetenschappelijk onderzoek, die wij in paragraaf 5 schetsen. We sluiten af met de samenvatting van de belangrijkste onderzoeksbevindingen.

\section{Totstandkoming van artikel 2:382a BW}

Op 17 mei 2006 is Richtlijn 2006/43/EG (richtlijn) van het Europese parlement en de Raad van de Europese Unie (Raad van ministers) betreffende de wettelijke controles van (geconsolideerde) jaarrekeningen gepubliceerd. Volgens overweging 5 beoogt de richtlijn een hoge mate van - maar 
geen volledige - harmonisatie van de voorschriften inzake de wettelijke controle van jaarrekeningen tot stand te brengen. Een belangrijk element van de wettelijke controle betreft de onafhankelijkheid van de controleur. Overweging 11 stelt hierover: 'Bedreigingen voor de onafhankelijkheid van een wettelijke auditor of auditkantoor zijn bijvoorbeeld een direct of indirect financieel belang in de gecontroleerde entiteit en de verrichting van bijkomende niet-controlediensten. Ook kan de hoogte van het van één gecontroleerde entiteit ontvangen honorarium en/of de honorariumstructuur een bedreiging vormen voor de onafhankelijkheid van een wettelijke auditor of auditkantoor. Tot de veiligheidsmaatregelen die kunnen worden genomen om deze bedreiging af te zwakken of weg te nemen, behoren verboden, beperkingen, andere beleids- en proceduremaatregelen alsmede openbaarmaking.' De openbaarmaking van de accountantshonoraria behoort tot de veiligheidsmaatregelen waarop ons onderzoek zich richt. Overweging 33 stelt dat, teneinde de relatie tussen de wettelijke auditor of het auditkantoor en de gecontroleerde entiteit transparanter te maken, de Richtlijnen 78/660/EEG en 83/349/EEG [deze richtlijnen staan bekend als de Vierde en de Zevende EEG-Richtlijn, toevoeging door de auteurs] zodanig dienen te worden gewijzigd dat zij voorschrijven dat het honorarium voor de wettelijke controle van jaarrekeningen en het honorarium voor niet-controlediensten in de toelichting bij de jaarrekening en de geconsolideerde jaarrekening moeten worden vermeld. Aan deze overweging is in artikel 49 inhoud gegeven. De letterlijke tekst luidt:

'Artikel 49

Wijziging van Richtlijn 78/66o/EEG en Richtlijn 83/349/EEG

1) Richtlijn $78 / 660 / E E G$, wordt als volgt gewijzigd:

a) in artikel 43, lid 1, wordt het volgende punt toegevoegd:

"15. afzonderlijk, de tijdens het boekjaar door de wettelijke auditor of het auditkantoor aangerekende totale honoraria voor de wettelijke controle van jaarrekeningen, de totale honoraria voor andere assurance-opdrachten, de totale honoraria voor belastingadviesdiensten en de totale honoraria voor andere niet-controlediensten. De lidstaten kunnen bepalen dat deze vereiste niet van toepassing is indien de vennootschap is opgenomen in de geconsolideerde jaarrekeningen die overeenkomstig artikel 1 van Richtlijn 83/349/ EEG moeten worden opgesteld, mits deze informatie in de toelichting bij de jaarrekeningen wordt vermeld."

Dit gewijzigde artikel 49 uit de Vierde Richtlijn is de basis van artikel 382a, zoals dat medio 2008 in Titel 9 boek 2 BW is opgenomen.

Wij signaleren hier het hybride karakter van de regeling. Enerzijds is zij gericht op de accountantsorganisaties, anderzijds is zij gericht op de jaarverslaggeving van onderne- mingen. Dit hybride karakter heeft naar onze mening voor de praktijk van de jaarverslaggeving tot uitvoeringsvragen geleid. Deze vragen worden in de volgende paragraaf besproken. Het hybride karakter blijkt ook uit de ondertekening van de wet van 12 juni 2008, waarin onder andere artikel 2:382a BW wordt geïntroduceerd. De minister van Financiën, als verantwoordelijke voor de Wta, is eerste ondertekenaar; de staatssecretaris voor Justitie die verantwoordelijk is voor het jaarrekeningenrecht, is tweede ondertekenaar. Volledigheidshalve volgt hierna de tekst van artikel 2:382a BW:

1. Opgegeven worden de in het boekjaar ten laste van de rechtspersoon gebrachte totale honoraria voor het onderzoek van de jaarrekening, totale honoraria voor andere controleopdrachten, totale honoraria voor adviesdiensten op fiscaal terrein en totale honoraria voor andere niet-controlediensten, uitgevoerd door de externe accountant en de accountantsorganisatie, genoemd in artikel 1, eerste lid, onder a en e, van de Wet toezicht accountantsorganisaties.

2. Indien de rechtspersoon dochtermaatschappijen heeft of de financiële gegevens van andere maatschappijen consolideert, worden de honoraria die in het boekjaar te hunnen laste zijn gebracht, in de opgave begrepen.

3. De honoraria hoeven niet opgegeven te worden door een rechtspersoon waarvan de financiële gegevens zijn geconsolideerd in een geconsolideerde jaarrekening waarop krachtens het toepasselijke recht de verordening van het Europees Parlement en de Raad betreffende de toepassing van internationale standaarden voor jaarrekeningen of de zevende richtlijn van de Raad van de Europese Gemeenschappen inzake het vennootschapsrecht van toepassing is.'

Kleine rechtspersonen zijn vrijgesteld van accountantscontrole (artikel 2:396 lid 7). Hierdoor zal het verschaffen van informatie over de accountantshonoraria ${ }^{1}$ bij kleine rechtspersonen vrijwel niet aan de orde zijn. ${ }^{2}$ Voor middelgrote rechtspersonen is artikel 2:382a BW niet van toepassing, mits de in dat artikel bedoelde gegevens aan de Stichting Autoriteit Financiële Markten op diens verzoek worden verstrekt. Deze regeling is opgenomen in artikel 2:397 lid 4 BW.

In de volgende paragraaf bespreken we de vragen van juridische en vaktechnische aard die zijn gerezen naar aanleiding van dit wetsartikel. In de daarop volgende paragraaf presenteren wij de resultaten van het jaarrekeningenonderzoek.

\section{Vragen van juridische en vaktechnische aard}

De vragen die dit wetsartikel heeft opgeroepen, zijn afkomstig van de beroepspraktijk van accountants. Wij baseren ons op Oosterhoff en Schoonderbeek (2009), de brief van de Raad 
voor de Jaarverslaggeving (RJ) aan de minister van Justitie, de NIVRA-wijzer 1 (2009) van het Koninklijk Nederlands Instituut van Registeraccountants (Koninklijk NIVRA), het interview met de voorzitter van de RJ (het Financieele Dagblad, juni 2009) en op vaktechnische artikelen van Böhmer en Van Beurden (2008) en van Molenbrugge (2008).

De vraag die regelmatig terugkomt, is of artikel 2:382a BW van toepassing is op rechtspersonen die de door de International Accounting Standards Board vastgestelde en door de Europese Commissie goedgekeurde standaarden $\left(\text { IFRS }^{*}\right)^{3}$ gebruiken bij het opstellen van de jaarrekening. Artikel 2:362 lid 9 BW benoemt de afdelingen en artikelen van Titel 9 die de rechtspersoon dient toe te passen indien de jaarrekening volgens IFRS ${ }^{*}$ wordt opgesteld. Aangezien artikel 2:362 lid 9 BW toepassing van artikel 2:382a niet noemt, zou kunnen worden geconcludeerd dat ondernemingen die IFRS* toepassen, de accountantskosten niet behoeven te vermelden. Naar onze mening is dat een verdedigbare maar toch een te beperkte opvatting. Dit zou inhouden dat beursgenoteerde ondernemingen de accountantshonoraria níet en de niet-beursgenoteerde ondernemingen de accountantshonoraria wél dienen te vermelden. Wij kunnen ons daarvoor geen redenen voorstellen. Volledigheidshalve merken wij op dat IFRS* geen standaard kent die voorschrijft dat de accountantshonoraria dienen te worden vermeld.

In de NIVRA-wijzer 1 (2009) wordt de stelling onderschreven dat een beoordeling van de onafhankelijkheid van de externe accountant en de accountantsorganisatie die een (geconsolideerde) jaarrekening heeft gecontroleerd, is gebaat bij het vermelden van de informatie over de honoraria van het netwerk van de accountantsorganisatie die ten laste van het boekjaar zijn gebracht. Echter, het Koninklijk NIVRA erkent dat de wettekst slechts informatie vraagt over de honoraria van de externe accountant en de accountantsorganisatie (zoals bedoeld in de Wta). Op grond hiervan geeft het Koninklijk NIVRA er de voorkeur an in de jaarrekening, uitgesplitst en voorzien van vergelijkende cijfers, de in rekening gebrachte honoraria van de externe accountant en de accountantsorganisatie zoals gedefinieerd in de Wta en het gehele netwerk waartoe de accountantsorganisatie behoort, te vermelden. Het Koninklijk NIVRA stelt voor een tabellarisch overzicht op te stellen voor het boekjaar en voor de vergelijkende cijfers van het voorgaand boekjaar, met in de eerste kolom de omschrijving van de verschillende honorariacategorieën, in de volgende kolommen uitgesplitst naar de desbetreffende accountant, het overig netwerk van de accountant en het totaal van beide.

Böhmer en Van Beurden (2008) en Molenbrugge (2008) signaleren dat de precieze afbakening van het netwerk niet wordt gegeven. Wij verwachten dat de controlerend accoun-
Tabel 1 Voorstel overzicht accountantskosten in de jaarrekening

\begin{tabular}{|l|c|c|c|}
\hline & X Accountants & $\begin{array}{c}\text { Overig } \mathbf{X} \\
\text { netwerk }\end{array}$ & $\begin{array}{c}\text { Totaal } \mathbf{X} \\
\text { netwerk }\end{array}$ \\
\hline Onderzoek van de jaarrekening & 0 & 0 & 0 \\
\hline Andere controleopdrachten & 0 & 0 & 0 \\
\hline Adviesdiensten op fiscaal terrein & 0 & 0 & 0 \\
\hline Andere niet-controlediensten & 0 & 0 & 0 \\
\hline Totaal & $\mathbf{0}$ & $\mathbf{0}$ & $\mathbf{0}$ \\
\hline
\end{tabular}

Bron: NIVRA-wijzer 1 (2009, p. 3)

tant een intensief contact onderhoudt met andere partijen die accountantswerkzaamheden verrichten. Om deze reden is het redelijk te veronderstellen dat de controlerend accountant het 'overig netwerk' nauwkeurig kan bepalen.

Dat de wetsaanpassing gecompliceerd is vormgegeven, mag blijken uit de volgende opmerking van Böhmer en Van Beurden (2008). Zij stellen dat de expliciete uitzondering van vermelding van de accountantskosten in de geconsolideerde jaarrekening in artikel 2:410 lid 1 BW een vergissing is van de wetgever. Echter, in de Memorie van Toelichting (Kamerstuk 31270 nr. 3) is de motivering aangetroffen voor het opnemen van artikel 2:382a in de uitzonderingen van artikel 2:410 lid 1 BW. De Memorie van Toelichting stelt: 'De richtlijn voegt aan de Zevende Richtlijn (...) ook het voorschrift toe dat informatie moet worden verstrekt over de accountantshonoraria (artikel 34, onderdeel 16). Dat is geregeld in artikel 2:382a lid 2 BW. Om te voorkomen dat de consolidatie dubbelop geregeld is, moet artikel 2:382a in artikel $410 \mathrm{BW}$ genoemd worden als artikel dat is uitgezonderd van overeenkomstige toepassing op de geconsolideerde jaarrekening.'

Oosterhoff en Schoonderbeek (2009, pp. 369-370) besteden hieraan ook de nodige aandacht. Zij constateren dat artikel 2:382a niet de consolidatiekring tot uitgangspunt neemt, maar dat de geconsolideerde vennootschappen en (nietgeconsolideerde) dochtermaatschappijen moeten worden opgenomen. Blijkbaar roept de zinsnede: 'Indien de rechtspersoon dochtermaatschappijen heeft of de financiële gegevens van andere maatschappijen consolideert,...' deze vraag op. Het woordje 'of zorgt hier voor de verwarring. Oosterhoff en Schoonderbeek lezen hierin dat ook de accountantskosten van de niet-geconsolideerde dochtermaatschappijen dienen te worden opgenomen. Een andere interpretatie is dat de accountantskosten van de geconsolideerde maatschappijen, dochtermaatschappijen in de groep en andere groepsmaatschappijen, dienen te worden gepubliceerd. In onze visie dienen de accountantskosten van de in de consolidatie betrokken maatschappijen te worden vermeld. De grondslag 
hiervoor is Kamerstuk $31270 \mathrm{nr}$. 3, waarin is aangegeven dat het de geconsolideerde jaarrekening betreft. ${ }^{4}$

Zoals hiervoor blijkt, zijn er tal van vragen en onduidelijkheden. Breij (2009, p. 30) stelt dat uit zijn analyse blijkt dat er bij de bedrijven verschillen in interpretatie optreden. Dit belemmert de duidelijkheid die wordt geboden. In de volgende paragraaf gaan wij in op de manier waarop in de praktijk van de externe verslaggeving is omgegaan met de vermelding van de accountantskosten in de jaarrekeningen.

\section{Empirisch onderzoek accountantskosten in de jaarrekening}

Wij hebben 94 jaarrekeningen 5 over 2008 van Nederlandse beursgenoteerde ondernemingen onderzocht. Om onderzoektechnische redenen hebben wij besloten jaarrekeningen van de volgende ondernemingen buiten het onderzoek te laten: ondernemingen die rapporteren in vreemde valuta, met meer dan één moedermaatschappij, met meer dan één accountant, zonder operationele activiteiten, met een negatieve omzet ${ }^{6}$ of zonder opgave van de omzet en met een gebroken boekjaar? De volledige opgave van de onderzochte ondernemingen met daarbij het absolute en relatieve belang van de honoraria voor het onderzoek van de jaarrekening is in de bijlage opgenomen. ${ }^{8}$

De eerste onderzoeksvraag is of beursgenoteerde ondernemingen de accountantskosten publiceren. In 89 (94,7\%) van de onderzochte jaarrekeningen is een opgave van de accountantskosten aangetroffen. In 87 jaarrekeningen zijn de honoraria voor het onderzoek van de jaarrekening afzonderlijk aangegeven en in twee jaarrekeningen was de opgave niet-gespecificeerd. In zeven gevallen ontbreken de vergelijkende cijfers voor 2007, hoewel die op basis van artikel 2:363 lid 5 BW wel mogen worden verwacht.

Vervolgens is nagegaan in welke mate de opgave is gesplitst naar de verschillende in artikel 2:382a BW genoemde onderdelen. Het ontbreken van een categorie betekent geenszins dat niet is voldaan aan de wet. Het is immers mogelijk dat bepaalde werkzaamheden in het desbetreffende jaar niet zijn verricht. Hiervan geeft tabel 2 het overzicht.

\section{Tabel 2 Segmentatie van de accountantskosten van Nederlandse beursgenoteerde ondernemingen}

\begin{tabular}{|l|c|c|}
\hline \multicolumn{1}{|c|}{ Gategorie } & $\begin{array}{c}\mathbf{2 0 0 8} \\
\mathbf{( n = 9 4 )}\end{array}$ & $\begin{array}{c}\mathbf{2 0 0 7} \\
(\mathbf{n = 9 4 )}\end{array}$ \\
\hline $\begin{array}{l}\text { Totale honoraria voor het onderzoek van de } \\
\text { jaarrekening }\end{array}$ & 87 & 80 \\
\hline Totale honoraria voor andere controleopdrachten & 71 & 70 \\
\hline $\begin{array}{l}\text { Totale honoraria voor adviesdiensten op fiscaal } \\
\text { terrein }\end{array}$ & 60 & 59 \\
\hline Totale honoraria voor andere niet-controlediensten & 67 & 61 \\
\hline Niet-gespecificeerd & 2 & 2 \\
\hline Geen opgave & 5 & 12 \\
\hline
\end{tabular}

De vorm van de opgave van de gesegmenteerde accountantskosten verschilt. De meeste ondernemingen presenteren een duidelijke tabel; sommige volstaan met een ontoegankelijke beschrijvende samenvatting. ${ }^{9}$ Twee ondernemingen volstaan met een niet-gespecificeerde weergave van het totaal van de accountantskosten. Deze weergave is naar onze mening niet in overeenstemming met artikel 2:382a. In de NIVRA-wijzer 1 (2009) wordt de voorkeur uitgesproken om de kosten van het accountantsnetwerk aan te geven. In 2008 wordt in 33 jaarrekeningen (dit is $37,1 \%$ van de 89 jaarrekeningen met vermelding van de accountantskosten) gesproken over het accountantsnetwerk. In een dergelijke toelichting wordt onderscheid gemaakt tussen de Nederlandse activiteiten, onder meer blijkend uit de rechtsvorm van de accountantsorganisatie en het overig netwerk van de desbetreffende accountantsorganisatie.

De verplichte vermelding van de accountantshonoraria maakt het voor het eerst mogelijk hiervan voor de Nederlandse beursgenoteerde ondernemingen een kwantitatief overzicht op te stellen. In totaal bedragen de accountantskosten in 2008 voor de onderzochte ondernemingen 313 mln. euro. Deze gegevens, zoals opgenomen in tabel 3, zijn nader uitgesplitst naar de wettelijk vereiste categorieën.

\section{Tabel 3 Kwantitatieve gegevens accountantskosten van Nederlandse beursgenoteerde ondernemingen $\left({ }^{*} € 1.000\right)$}

\begin{tabular}{|c|c|c|c|c|c|c|c|c|}
\hline \multirow{2}{*}{ Bategorie } & \multicolumn{4}{|c|}{2008} & \multicolumn{4}{|c|}{2007} \\
\hline & Totaal & Gemiddeld & Maximum & Minimum & Totaal & Gemiddeld & Maximum & Minimum \\
\hline Honoraria voor het onderzoek van de jaarrekening & 229.663 & 2.640 & 46.000 & 22 & 241.520 & 3.019 & 61.000 & 31 \\
\hline Honoraria voor andere controleopdrachten & 28.018 & 395 & 5.200 & $0^{10}$ & 30.719 & 379 & 7.000 & 0 \\
\hline Honoraria voor adviesdiensten op fiscaal terrein & 22.762 & 379 & 3.000 & 0 & 20.948 & 355 & 5.000 & 0 \\
\hline Honoraria voor andere niet-controlediensten & 32.448 & 484 & 7.000 & 0 & 23.010 & 377 & 3.693 & 0 \\
\hline Totaal gespecificeerde honoraria & 312.891 & & & & 316.197 & & & \\
\hline Niet-gespecificeerd & 230 & 115 & 115 & 115 & 183 & 92 & 142 & 41 \\
\hline
\end{tabular}


Niet verrassend, maar voor het eerst gekwantificeerd, blijkt het grote belang van de jaarrekeningcontrole voor de accountantsrekening. De honoraria voor het onderzoek van de jaarrekening betreffen $73,4 \%\left(76,4 \%^{11}\right)$ van de accountantskosten. Het relatieve belang van de overige genoemde honoraria zijn:

- honoraria voor andere controleopdrachten 9,0\% (9,7\%);

- honoraria voor adviesdiensten op fiscaal terrein $7,3 \%$ $(6,6 \%) ;$ en

- honoraria voor andere niet-controlediensten 10,4\% (10,6\%).

In vergelijking met 2007 zijn de gespecificeerde honoraria in 2008 met 1,0\% gedaald. Ook de honoraria voor het onderzoek van de jaarrekening $(5,0 \%)$ en de honoraria voor andere controleopdrachten $(8,8 \%)$ zijn gedaald. De honoraria voor adviesdiensten op fiscaal terrein $(8,7 \%)$ en de honoraria voor andere niet-controlediensten $(41,0 \%)$ zijn gestegen. Incidenteel wordt in de toelichting een verklaring gegeven met betrekking tot de ontwikkeling van de accountantskosten. ${ }^{12}$

Interessant is de verdeling van de onderzochte ondernemingen over de verschillende accountantsorganisaties. Tabel 4 geeft het overzicht van de accountantsorganisaties en het aantal ondernemingen waarbij zij zijn betrokken.

De dominantie in aantallen cliënten van de big four (Deloitte, E\&Y, KPMG en PwC) is duidelijk. Wisseling van accountantsorganisatie en wisseling van controlerend accountant komen incidenteel voor. De vier wisselingen van 2008 ten opzichte van 2007 zijn: Draka Holding van KPMG naar Deloitte, HITT van BDO naar Deloitte, Schuitema van Deloitte naar KPMG en Tiscali van E\&Y naar Deloitte. Twaalf keer is een wisseling van tekenend accountant binnen dezelfde accountantsorganisatie voorgekomen, vijf keer ontbreken de gegevens van de tekenend accountant.

De tabellen 5 en 6 geven de gemiddelde kosten per cliënt per honorariumcategorie per accountantsorganisatie voor respectievelijk 2008 en 2007.

\section{Tabel 4 Aantal Nederlandse beursgenoteerde ondernemingen per accountantsorganisatie}

\begin{tabular}{|l|c|c|}
\hline \multirow{2}{*}{\multicolumn{1}{|c|}{ Accountantsorganisatie }} & \multicolumn{2}{c|}{ Aantal ondernemingen } \\
\cline { 2 - 3 } & $\mathbf{2 0 0 8}$ & $\mathbf{2 0 0 7}$ \\
\hline BDO CampsObers Audit \& Assurance B.V. (BDO) & 5 & 6 \\
\hline Deloitte Accountants B.V. (Deloitte) & 15 & 14 \\
\hline Ernst \& Young Accountants LLP (E\&Y) & 23 & 24 \\
\hline HLB Van Daal \& Partners N.V. Accountants \& Belastingadviseurs (Van Daal) & & 1 \\
\hline KPMG Accountants N.V. (KPMG) & 30 & 29 \\
\hline Mazars Paardekooper Hoffman Accountants N.V. (Mazars) & 4 & 4 \\
\hline PricewaterhouseCoopers Accountants N.V. (PwC) & 15 & 15 \\
\hline Onbekend ${ }^{13}$ & 2 & 1 \\
\hline Totaal & $\mathbf{9 4}$ & $\mathbf{9 4}$ \\
\hline
\end{tabular}

\section{Tabel 5 Gemiddelde accountantskosten per cliënt per accountantsorganisatie (2008; * $€$ 1000)}

\begin{tabular}{|l|r|r|r|r|r|c|}
\hline Categorie & \multicolumn{1}{|c|}{ BDO } & \multicolumn{1}{|c|}{ Deloitte } & \multicolumn{1}{c|}{ E\&Y } & \multicolumn{1}{|c|}{ KPMG } & Mazars & PwC \\
\hline $\begin{array}{l}\text { Honoraria voor het onderzoek } \\
\text { van de jaarrekening }\end{array}$ & 148,5 & $1.139,1$ & $3.998,3$ & $2.377,0$ & 171,0 & $3.833,6$ \\
\hline $\begin{array}{l}\text { Honoraria voor andere } \\
\text { controleopdrachten }\end{array}$ & 79,3 & 392,6 & 458,3 & 35,0 & 695,0 \\
\hline $\begin{array}{l}\text { Honoraria voor adviesdiensten } \\
\text { op fiscaal terrein }\end{array}$ & & 325,0 & 800,1 & 529,9 & 117,0 & 416,4 \\
\hline $\begin{array}{l}\text { Honoraria voor andere } \\
\text { niet-controlediensten }\end{array}$ & 86,0 & 141,0 & 766,7 & 633,8 & 10,0 & 629,2 \\
\hline Niet-gespecificeerd & & & 115,0 & & 115,0 & \\
\hline Totaal & $\mathbf{2 3 4 , 5}$ & $\mathbf{1 . 6 8 4 , 4}$ & $\mathbf{6 . 0 7 2 , 7}$ & $\mathbf{3 . 9 9 9 , 0}$ & $\mathbf{4 4 8 , 0}$ & $\mathbf{5 . 5 7 5 , 0}$ \\
\hline
\end{tabular}

Omdat cliënten van de verschillende organisaties sterk verschillen, dienen de gegevens uit de tabellen 5 en 6 voorzichtig te worden geïnterpreteerd (zie ook Van Schaik, 2003b, pp. 308-309). De gemiddelde honoraria voor het onderzoek

Tabel 6 Gemiddelde accountantskosten per cliënt per accountantsorganisatie (2007; *€ 1000)

\begin{tabular}{|l|c|r|r|r|r|c|}
\hline Categorie & BDO & Deloitte & E\&V & \multicolumn{1}{c|}{ KPMG } & Mazars & PwC \\
\hline Honoraria voor het onderzoek van de jaarrekening & 253,0 & $1.271,4$ & $4.645,8$ & $2.307,1$ & 169,0 & $4.465,4$ \\
\hline Honoraria voor andere controleopdrachten & & 100,9 & 637,6 & 346,7 & 35,0 & 955,7 \\
\hline Honoraria voor adviesdiensten op fiscaal terrein & & 297,4 & $1.076,1$ & 458,2 & 84,0 & 283,9 \\
\hline Honoraria voor andere niet-controlediensten & 132,5 & 78,6 & 351,8 & 667,5 & & 399,4 \\
\hline Niet-gespecificeerd & & & 142,0 & & 41,0 & \\
\hline Totaal & $\mathbf{3 8 5 , 5}$ & $\mathbf{1 . 7 4 8 , 3}$ & $\mathbf{6 . 8 5 3 , 3}$ & $\mathbf{3 . 7 7 9 , 2}$ & $\mathbf{3 2 9 , 0}$ & $\mathbf{6 . 1 0 4 , 4}$ \\
\hline
\end{tabular}


van de jaarrekening zijn bij E\&Y (13,9\%), PwC (14,0\%) en Deloitte $(10,4 \%)$ gedaald, terwijl bij KPMG de honoraria $(3,0 \%)$ zijn gestegen. ${ }^{14}$ Uit de tabellen 5 en 6 is het relatieve aandeel van de honoraria voor het onderzoek van de jaarrekening ten opzichte van de totale accountantskosten te bepalen. Deze verhouding wordt weleens gezien als een indicatie voor de (on)afhankelijkheid van de accountant. ${ }^{15}$ Indien het honorarium voor het onderzoek van de jaarrekening ten opzichte van de totale accountantskosten laag is, zou dit een aanwijzing kunnen zijn dat de onafhankelijkheid van de accountant in het gedrang komt. Bij Mazars is dit percentage 38,2\% $(51,4 \%)$, aanzienlijk lager dan bij de overige accountantsorganisaties. Daar variëren de percentages tussen de 59,4\% en $68,8 \%$ (61,0\%-73,2\%). Op ondernemingsniveau, zie ook de bijlage van de onderzochte ondernemingen, blijkt dat de percentages per jaar grote verschillen kunnen vertonen. De Porceleyne Fles heeft in 2008 het laagste percentage, $19,9 \%$, in 2007 is de verhouding 93,9\%. OctoPlus heeft in 2007 het laagste percentage, $17,2 \%$, in 2008 is de verhouding $72,2 \%$. Zonder nader onderzoek van de feiten en omstandigheden, zie ook Van Schaik (2003b), kunnen op basis van alleen deze cijfers geen harde oordelen worden geformuleerd over de onafhankelijkheid van de accountant.

Tabel 7 geeft de verdeling van de accountantskosten over de accountantsorganisaties voor 2008 en de concentratiegraad voor de drie grootste $\left(\mathrm{C}_{3}\right)$ accountantsorganisaties.

Op basis van de verantwoorde bedragen in de jaarrekeningen van de onderzochte Nederlandse beursgenoteerde ondernemingen is de concentratiegraad berekend voor de drie grootste marktpartijen. Hieruit trekken wij de conclusie dat in Nederland sprake is van een big three. De totale bedragen van E\&Y, KPMG en PwC omvatten 93,3\% van de totale accountantskosten en ook binnen de onderscheiden categorieën ligt het marktaandeel van de big three boven de $90 \%$. De concentratiegraad is ook uitgedrukt in cliënteigenschappen. Hiervoor zijn de omzet en het balanstotaal van de onderzochte ondernemingen verdeeld over de accountantskosten. De grote drie accountantsorganisaties hebben een marktaandeel van $88,7 \%$ van de totaal gecontroleerde omzet en $98,5 \%$ van het totaal gecontroleerde balanstotaal. Dit bevestigt het beeld van de big three in Nederland bij beursgenoteerde ondernemingen.

NIVRA-wijzer 1 (2009) geeft een voorbeeld van een duidelijke tabellarische vermelding van de accountantshonoraria, zie figuur 1. Dit noemen wij de best practice. Breij (2009, p. 31) rapporteert dat 14 van de 44 ondernemingen $(31,8 \%)$ de accountantskosten vermelden in de door het NIVRA aanbevolen tabel. Een voorbeeld hiervan is gevonden in de jaarrekening van DPA Flex (2008, p. 92), zie figuur 1.

In één overzichtelijke tabel zijn de gepresenteerde gegevens direct af te lezen.

\section{Eerder onderzoek naar accountantshonoraria}

De introductie van artikel 2:382a BW is de aanleiding voor dit artikel. Om die reden is aandacht besteed aan de totstandkoming van de wettelijke bepalingen en zijn de praktische vragen bij dit wetsartikel behandeld. In het jaarrekeningenonderzoek zijn de kwantitatieve gegevens besproken. Deze paragraaf bespreekt eerder wetenschappelijk onderzoek naar de vermelding van accountantshonoraria in de jaarrekening. Het doel hiervan is de praktische waarnemingen te plaatsen in de wetenschappelijke context om hiermee de mogelijkheden voor vervolgonderzoek te schetsen.

Wij beginnen met het overzichtsartikel van Hay et al. (2006).

Tabel 7 Verdeling van de accountantskosten in $€ 1000$ over zes accountantsorganisaties en de concentratiegraad van de big three (2008)

\begin{tabular}{|c|c|c|c|c|c|c|c|c|}
\hline Categorie & BDO & Deloitte & E\&Y & KPMG & Mazars & PwC & $\begin{array}{c}\text { Totaal } \\
\text { (percentage) }\end{array}$ & B3 \\
\hline $\begin{array}{l}\text { Honoraria voor het onderzoek van de } \\
\text { jaarrekening }\end{array}$ & 594 & 15.947 & 83.964 & 71.309 & 171 & 57.504 & $\begin{array}{c}229.489 \\
(73,3)\end{array}$ & 92,7 \\
\hline Honoraria voor andere controleopdrachten & & 872 & 7.067 & 10.998 & 35 & 9.045 & $\begin{array}{c}28.017 \\
(9,0)\end{array}$ & 96,8 \\
\hline $\begin{array}{l}\text { Honoraria voor adviesdiensten op fiscaal } \\
\text { terrein }\end{array}$ & & 1.620 & 5.601 & 10.011 & 117 & 5.413 & $\begin{array}{c}22.762 \\
(7,3)\end{array}$ & 92,4 \\
\hline Honoraria voor andere niet-controlediensten & 344 & 987 & 11.501 & 11.408 & 10 & 8.180 & $\begin{array}{c}32.430 \\
(10,4)\end{array}$ & 95,9 \\
\hline Niet-gespecificeerd & & & 115 & & 115 & & $\begin{array}{l}230 \\
(0,1)\end{array}$ & $\begin{array}{l}\text { niet van } \\
\text { toepassing }\end{array}$ \\
\hline Totaal (percentage) & $\begin{array}{l}938 \\
(0,3)\end{array}$ & $\begin{array}{r}19.426 \\
(6,2)\end{array}$ & $\begin{array}{r}108.248 \\
(34,6)\end{array}$ & $\begin{array}{r}103.726 \\
(33,1)\end{array}$ & $\begin{array}{r}448 \\
(0,1)\end{array}$ & $\begin{array}{r}80.142 \\
(25,6)\end{array}$ & $\begin{array}{l}312.928^{16} \\
(100)\end{array}$ & 93,3 \\
\hline
\end{tabular}


Figuur 1 Honoraria in de jaarrekening van DPA Flex

De volgende honoraria van Mazars zijn opgenomen in de winst-en-verliesrekening 2008 en 2007.

\begin{tabular}{|c|c|c|c|c|c|c|}
\hline & & & 2008 & & & 2007 \\
\hline & $\begin{array}{r}\text { Mazars } \\
\text { Accountants }\end{array}$ & $\begin{array}{r}\text { Overig } \\
\text { Mazars } \\
\text { Netwerk }\end{array}$ & $\begin{array}{r}\text { Mazars } \\
\text { totaal }\end{array}$ & $\begin{array}{r}\text { Mazars } \\
\text { Accountants }\end{array}$ & $\begin{array}{r}\text { Overig } \\
\text { Mazars } \\
\text { Netwerk }\end{array}$ & $\begin{array}{r}\text { Mazars } \\
\text { totaal }\end{array}$ \\
\hline Onderzoek van de jaarrekening & 171 & - & 171 & 169 & - & 169 \\
\hline Andere controle-opdrachten & 35 & - & 35 & 35 & - & 35 \\
\hline Andere niet-controlediensten & - & 10 & 10 & - & - & - \\
\hline Totaal & 206 & 127 & 333 & 204 & 84 & 288 \\
\hline
\end{tabular}

Kennisname van dit artikel is vereist voor onderzoekers op het gebied van accountantskosten in de jaarrekening. Vervolgens bespreken wij publicaties van drie Nederlandse onderzoekers. Langendijk (1994 en 1997) zijn twee bekende onderzoeken uit de periode vóór de verplichte vermelding van accountantskosten in de jaarrekening van Nederlandse ondernemingen. Van Schaik (2003a en 2003b) bespreekt respectievelijk de vraagstukken rondom de prijsbepaling van de jaarrekeningcontrole en de voor- en nadelen van de openbaarmaking van accountantshonoraria. Breij (2009) geeft een kwantitatieve analyse van de accountantshonoraria in de jaarrekening van Nederlandse ondernemingen.

De meta-analyse van Hay et al. (2006) schetst een indrukwekkend beeld van het accountantskostenonderzoek over de periode 1977 tot 2003. Het baanbrekende onderzoek van Simunic (1980) wordt hierbij gezien als basisartikel voor vervolgonderzoek. In navolging van Simunic (1980) hanteren empirische onderzoeken veelal een basismodel in de vorm van:

$\ln f_{\mathrm{i}}=b_{\mathrm{o}}+b_{1} \ln A_{\mathrm{i}}+\Sigma b_{\mathrm{k}} g_{\mathrm{ik}}+\Sigma b_{\mathrm{e}} g_{\mathrm{ie}}+e i$

met:

- $\ln f_{\mathrm{i}}$ als de natuurlijke logaritme van het accountantshonorarium (afhankelijke variabele);

- $\ln A_{\mathrm{i}}$ als de natuurlijke logaritme van een groottemaatstaf(veelal totaal activa); en

- $g_{i k}$ en $g_{\text {ie }}$ als twee groepen factoren die mogelijk van invloed zijn op de hoogte van het honorarium, waarbij $\mathrm{k}$ de controlevariabelen aanduidt en e de experimentele (onafhankelijke) variabelen.

Als door regressieanalyse wordt aangetoond dat de coëfficiënten van de experimentele variabelen significant zijn, wordt geacht dat het veronderstelde verband tussen de variabele en de honoraria bestaat. Hay et al. (2006) hebben 147 analyses beoordeeld, waarin 186 onafhankelijke varia- belen zijn getoetst. Er is een indeling gemaakt naar eigenschappen van de onderneming (zoals omzet of activa) en naar accountantsorganisatie (zoals big four of afzonderlijke accountantsorganisaties). Hun conclusie is dat de honoraria voor het onderzoek van de jaarrekening samenhangen met de grootte, de complexiteit en het risico van de gecontroleerde organisatie. Ook geven zij nog vijf onderzoeksvelden aan waarin het verband met de honoraria voor de jaarrekeningcontrole nader kan worden onderzocht. Dit zijn de eigendomsstructuur, de betrouwbaarheid van de interne beheersing, de governancestructuur, de kwaliteit van de accountant en de samenstelling van de accountantshonoraria. Hay et al. (2006) verwijzen bijvoorbeeld naar eerdere onderzoeken op dit gebied, zoals O'Sullivan en Diacon (2002). ${ }^{17} \mathrm{Zij}$ onderzoeken het verband tussen enerzijds de eigendomsstructuur en de governancestructuur en anderzijds de accountantshonoraria. De invloed van de betrouwbaarheid van de interne beheersing op de accountantskosten is onder meer onderzocht door Abbott et al. (2003). De relatie tussen de kwaliteit en de grootte van de accountantsorganisatie is het onderwerp van de klassieke studie van DeAngelo (1981). De samenstelling van de accountantshonoraria en de onafhankelijkheid van accountants zijn bijvoorbeeld onderzocht door DeFond et al. (2002) en Ghosh et al. (2009). ${ }^{18}$ Een gedetailleerde bespreking van de uitkomsten van het omvangrijke onderzoek van Hay et al. (2006) valt buiten het bestek van dit artikel.

In de jaren negentig van de twintigste eeuw heeft Langendijk (bijvoorbeeld 1994 en 1997) verschillende studies verricht naar de markt voor accountantsdiensten. De gegevens heeft hij (Langendijk, 1997) verzameld door middel van vragenlijsten. Bezwaren bij vragenlijstenonderzoek zijn dat de onderzoeker afhankelijk is van de medewerking van de ondervraagde en dat hij moet vertrouwen op de juistheid van de gegevensverstrekking. Met de introductie van artikel 2:382a BW zijn beide bezwaren vervallen. Gegevens over accountantshonoraria stellen onderzoekers 
in staat om op basis van betrouwbare jaarrekeninggegevens overeenkomstige onderzoeken ook voor ondernemingen in de EU uit te voeren. Het is dan echter wel noodzakelijk dat de opstellers van jaarrekeningen informatie met dezelfde inhoud verstrekken. Uit het jaarrekeningenonderzoek in paragraaf 4 en ook uit het onderzoek van Breij (2009, p. 30) blijkt dat dat nog niet het geval is.

Naar aanleiding van de onafhankelijkheidsvoorschriften van de beroepsorganisaties van accountants, NIVRA en NOVAA, bespreekt Van Schaik (2003a) het spanningsveld tussen het maatschappelijk belang van een in wezen en in schijn onafhankelijke accountant, het belang van de accountant om een cliënt te winnen of te behouden en het streven van de onderneming naar lage accountantskosten. $\mathrm{Hij}$ analyseert in het bijzonder het voorschrift tegen low balling, dat is het aanbieden van de controle van de jaarrekening beneden de kostprijs. Zijn conclusie is dat accountants geen auditfee in rekening mogen brengen die beneden de differentiële kosten ligt en dat bij een vasteprijsafspraak een clausule voor meerwerk dient te worden opgenomen.

Van Schaik (2003b) bepleit voorzichtigheid bij het doen van uitspraken over de onafhankelijkheid van de accountant op basis van openbaar gemaakte vergoedingen voor accountantscontrole en overige dienstverlening. Als redenen geeft hij hiervoor aan dat er inconsistenties zijn in de informatieverstrekking en dat er onbekendheid is over de feiten en omstandigheden die hebben geleid tot deze vergoedingen. Bovendien vraagt hij zich af of de verhouding tussen het honorarium voor het onderzoek van de jaarrekening en het honorarium voor de overige dienstverlening een betrouwbare maatstaf is voor de onafhankelijkheid van de accountant. In zijn visie ligt het belang van de accountant bij het totale honorarium en niet bij de samenstelling ervan. Wij willen hierbij opmerken dat Breij (2009) inconsistenties in de informatieverstrekking heeft vastgesteld. De feiten en omstandigheden spelen een belangrijke rol bij de verdeling van de accountantshonoraria bij de individuele onderneming, maar minder bij de analyse van een grote groep ondernemingen over meer dan een jaar, waarin de verschillende feiten en omstandigheden elkaar compenseren.

Verplichte vermelding van accountantskosten in de jaarrekening van ondernemingen biedt, zo blijkt uit de besproken literatuur, nieuwe mogelijkheden en uitdagingen voor empirisch onderzoek naar de variabelen die de hoogte en samenstelling van de accountantshonoraria verklaren.

\section{Samenvatting}

De aanleiding voor het onderzoek is de verplichting voor ondernemingen om met ingang van de jaarrekening over 2008 de accountantskosten te vermelden. In paragraaf 2 is het hybride karakter van de regeling aangegeven. Enerzijds is zij via de Wta gericht op de accountantsorganisaties, anderzijds is zij via artikel 2:382a BW gericht op jaarverslaggeving van ondernemingen. De regeling is op de accountantsorganisaties gericht, omdat het publiek inzicht moet hebben in de relaties tussen de controleur en de gecontroleerde. Té grote afhankelijkheid van een of enkele klanten kan de onafhankelijkheid van de accountantsorganisatie in gevaar brengen. Ondernemingen zijn verplicht de accountantskosten in vier categorieën in de jaarrekening te vermelden: honoraria voor het onderzoek van de jaarrekening, honoraria voor andere controleopdrachten, honoraria voor adviesdiensten op fiscaal terrein en honoraria voor andere niet-controlediensten. De jaarrekeningverantwoording leidt tot praktische vragen. Een vraag is of ondernemingen die volgens IFRS ${ }^{*}$ rapporteren deze informatie dienen op te nemen. De letter van de wet vereist de vermelding niet.

Om de vragen te beantwoorden, hebben wij een jaarverslagenonderzoek onder 94 beursgenoteerde ondernemingen uitgevoerd. Het blijkt dat ondernemingen die volgens IFRS ${ }^{*}$ rapporteren, op vijf uitzonderingen na de accountantskosten rapporteren. Twee ondernemingen geven de vereiste onderverdeling niet.

Uit de kwantitatieve gegevens blijkt verder dat in Nederland gesproken kan worden van de big three. In volgorde van het belang van de vermelde honoraria voor het onderzoek van de jaarrekening zijn dit E\&Y, KPMG en PwC.

De resultaten van ons onderzoek schetsen voor het eerste jaar dat de vermelding verplicht is, het kwantitatieve beeld van de accountantskosten. Verder onderzoek kan een vergelijking met andere landen in de EU omvatten en ontwikkelingen van de accountantskosten in de tijd. Dit onderzoek is inventariserend van aard. Later onderzoek kan zich richten op verklaringen van de verschillen in accountantskosten.

Zoals uit eerder onderzoek naar accountantshonoraria blijkt, kunnen deze gegevens worden gebruikt voor het verkrijgen van kennis en inzicht in de variabelen die de hoogte en samenstelling van de accountantshonoraria verklaren. Daarvoor is evenwel noodzakelijk dat de inhoud van de informatieverstrekking wordt verduidelijkt. 
Abbott, L.J., S. Parker, G.K. Peters en K. Raghunandan (2003), The association between audit committee characteristics and audit fees, Auditing: A Journal of Practice \& Theory, vol. 22, по. 2, pp. 17-32.

- Böhmer, S. en B. van Beurden (2008), Vermelding accountantskosten in de jaarrekening, Inform, Vaktechnisch bulletin, december 2008, pp. 4-7.

- Breij, E. (2009), Accountantshonoraria in de jaarrekening, De Accountant, oktober 2009, no. 10, pp. 30-33.

DeAngelo, L.E. (1981), Auditor size and audit quality, Journal of Accounting and Economics, vol. 3, no. 3, pp. 183-199.

- DeFond, M.L., K. Raghunandan en K.R. Subramanyam (2002), Do non-audit service fees impair auditor independence? Evidence from going concern audit opinions, Journal of Accounting Research, vol. 40, no. 4, pp. 12471274

- Ghosh, A., S. Kallapur en D. Moon (2009), Audit and non-audit fees and capital market perceptions of auditor independence, Journal of Accounting and Public Policy, vol. 28, no. 5, pp. 369-385.

- Het Financieele Dagblad (23 juni 2009), 'Kosten accountant niet duidelijk', geraadpleegd via http://www.accountancynieuws.nl/actueel/ accountancymarkt/rj-voorzitter-wijze-vanopenbaar-maken.78953.lynkx, dd. 25-06-2009.

- Hay, D.C., W.R. Knechel en N. Wong (2006), Audit fees: A meta-analysis of the effect of supply and demand attributes, Contemporary Accounting Research, vol. 23, no. 1, pp. 141-191.

- Koninklijk Nederlands Instituut van Registeraccountants (2009), NIVRA-wijzer 1: Vermelding accountantshonorarium in de jaarrekening, 13 februari.

- Langendijk, H.P.A.J. (1994), De markt voor de wettelijk verplichte accountantscontrole in Nederland: enkele kwantitatieve en kwalitatieve aspecten. Den Haag: Delwel (proefschrift).
Langendijk, H. (1997), The market for audit services in the Netherlands, The European Accounting Review, vol. 6, no. 2, pp. 253-264.

- Molenbrugge, T. (2008), Accountantskosten in de jaarrekening, Spotlight, Vaktechnisch bulletin van PricewaterhouseCoopers Accountants, vol. 15, no. 4, pp. 21-23.

口 Oosterhoff, G.P. en W.J. Schoonderbeek (2009), Knelpunten bij de opgave van de honoraria van de accountant in de jaarrekening Ondernemingsrecht, 2009-8, pp. 367-371.

- O'Sullivan, N. en S.R. Diacon (2002), The impact of ownership, governance and non-audit services on audit fees: Evidence from the insurance industry, International Journal of Auditing, vol. 6, no. 1, pp. 93-107.

- Raad voor de Jaarverslaggeving, Richtlijnen voor de jaarverslaggeving voor grote en middelgrote rechtspersonen (jaareditie 2008), Deventer: Kluwer.

Raad voor de Jaarverslaggeving, brief dd. 26 februari 2009, betreft: Vermelding van accountantshonoraria ex artikel 2:382a BW, http://www.rjnet.nl/pdf/UC_09_02_26_ Brief_aan_dhr_Hirsch_Ballin.pdf.

- Schaik, F.D.J. van (2003a), Een toereikende vergoeding voor de jaarrekeningcontrole, Maandblad voor Accountancy en Bedriffseconomie, vol. 77, no. 6, juni, pp. 254-260.

- Schaik, F.D.J. van (2003b), Openbaar maken van accountantshonoraria, Maandblad voor Accountancy en Bedrijfseconomie, vol. 77, no. 7/8, juli/augustus, pp. 306-312.

- Simon, D.T. en M.H. Taylor (2002), A survey of audit pricing in Ireland, International Journal of Auditing, vol. 6, no. 1, pp. 3-12.

- Simunic, D.A. (1980), The pricing of audit services: Theory and evidence, Journal of Accounting Research, vol. 22, no. 3, pp. 161-190. - Tweede Kamer, Kamerstuk 31270 Wijziging van de Wet toezicht accountantsorganisaties en Boek 2 van het Burgerlijk Wetboek, ter implementatie van richtlijn nr. 2006/43/EG van het Europees Parlement en de Raad van de Europese Unie van 17 mei 2006 betreffende de wettelijke controles van jaarrekeningen en geconsolideerde jaarrekeningen, tot wijziging van de Richtlijnen 78/660/EEG en 83/349/EEG van de Raad, en houdende intrekking van Richtlijn 84/253/EEG van de Raad (PbEU L 157).

Tweede Kamer, Kamerstuk 29737 Wijziging van boek 2 van het Burgerlijk Wetboek ter uitvoering van Verordening (EG) Nr. 1606/2002 van het Europees Parlement en de Raad van 19 juli 2002 betreffende de toepassing van internationale standaarden voor jaarrekeningen (Pb EG L 243), van Richtlijn nr. 2001/65/EG van het Europees Parlement en de Raad van 27 september 2001 tot wijziging van de Richtlijnen 78/660/EEG, 83/349/EEG en 86/635/EEG

met betrekking tot de waarderingsregels voor de jaarrekening en de geconsolideerde jaarrekening van bepaalde vennootschapsvormen evenals van banken en andere financiële instellingen (Pb EG L 283), en van Richtlijn 2003/51/EG van het Europees Parlement en de Raad van 18 juni 2003 tot wijziging van de Richtlijnen 78/660/ EEG, 83/349/EEG, 86/635/EEG en 91/674/ EEG van de Raad betreffende de jaarrekening en de geconsolideerde jaarrekening van bepaalde vennootschapsvormen, banken en andere financiële instellingen, en verzekeringsondernemingen (Pb EG L 178) (Wet uitvoering IAS-verordening, IAS 39-richtlijn en moderniseringsrichtlijn).

- Wet van 12 juni 2008, houdende wijziging van de Wet toezicht accountantsorganisaties en Boek 2 van het Burgerlijk Wetboek, ter implementatie van richtlijn nr. 2006/43/EG van het Europees Parlement en de Raad van de Europese Unie van 17 mei 2006 betreffende de wettelijke controles van jaarrekeningen en geconsolideerde jaarrekeningen, tot wijziging van de Richtlijnen 78/660/EEG en 83/349/EEG van de Raad, en houdende intrekking van Richtlijn 84/253/EEG van de Raad (PbEU L 157). 
1. Kamerstuk $31270 \mathrm{nr} .3$, p. 28 verwijst in dit verband naar artikel 2:396 lid 5 BW. Wij hebben de daar genoemde vrijstelling niet aangetroffen. De tekst van artikel 2:396 lid 5 BW luidt: 'Het in artikel 378 lid 1 genoemde overzicht wordt slechts gegeven voor de herwaarderingsreserve, behoudens de tweede zin van artikel 378 lid 3; opgegeven worden het aantal geplaatste aandelen en het bedrag per soort, aantal en bedrag van de in het boekjaar uitgegeven aandelen en van de aandelen en certificaten daarvan die de rechtspersoon of een dochtermaatschappij voor eigen rekening houdt. De artikelen 380, 381 leden 2 en 3, 381b, aanhef en onder a, en 383 lid 1 zijn niet van toepassing.' De verwijzing naar artikel 382a ontbreekt hier.

2 Indien kleine rechtspersonen, ondanks de vrijstelling, toch accountantscontrole zouden toepassen, dan zijn zij volgens ons ook gehouden informatie over de accountantshonoraria te verstrekken.

3 Met IFRS* (IFRS-sterretje) doelt de RJ op 'de door de International Accounting Standards Board vastgestelde en door de Europese Commissie goedgekeurde standaarden', zoals omschreven in artikel 2:362 lid 8 BW. Zie Richtlijn 100.102.

4 'Artikel 49, tweede lid, van de richtlijn, dat eenzelfde bepaling voor de geconsolideerde jaarrekening voorschrijft, wordt opgenomen in het BW door in het tweede lid van artikel 2:382a BW de consolidatie van de informatie over de honoraria voor te schrijven.' Kamerstuk 31270 nr. 3, p. 26. 5 De elektronische versies zoals gepubliceerd op de website van de desbetreffende onderneming. Wij hebben hiervoor gekozen omdat dit de jaarrekening is die door externe gebruikers (als eerste) wordt geraadpleegd. Ondernemingen proberen actief het gebruik van de papieren versies terug te dringen.

6 Dit betreft bijvoorbeeld exploitatie- of ontwikkelingsmaatschappijen van vastgoed die in 2008 het hoge negatieve herwaarderingsresultaat verwerken in de opbrengsten uit vastgoedbeleggingen.

7 Ahold en Schuitema, die afsluiten per respectievelijk 29 december en 28 december 2008, zijn gezien het beperkte verschil wel in het onderzoek betrokken.

8 Breij (2009, p. 30) heeft de buitenlandse rechtspersonen wel opgenomen in de bij het artikel behorende tabel. In de analyse laat hij deze rechtspersonen buiten beschouwing

9 Zie bijvoorbeeld de jaarrekening van DSM (2008, p. 158) en Tie Holding (2008, p. 103). In veel woorden (bij DSM 142; Tie 82), wordt de informatie over de accountantskosten verstrekt. 10 Het bedrag $€ 0$ is vermeld indien de onderneming dit zelf aangeeft. Indien de opgave ontbreekt is de desbetreffende cel blanco gelaten. Daardoor wordt het gemiddelde alleen berekend indien een opgave is verstrekt.

11 De cijfers tussen de haakjes zijn de cijfers van 2007. Deze verkorte schrijfwijze is in het vervolg van het artikel toegepast.

12 Vier voorbeelden hiervan zijn: 'De aan controle gerelateerde werkzaamheden 2007 betreffen onder andere werkzaamheden ten behoeve van het prospectus in het kader van de overname van Alex beleggersbank' (Binck Bank). 'In 2008 omvatten de overige assurance-services en overige diensten additionele services met betrekking tot het ontvlechtingsproces van DSM-activiteiten. . .' (DSM). 'Een groot deel van de controleactiviteiten over 2007 werd in 2008 uitgevoerd' (OctoPlus). 'In 2007 werd er ook 115.000 euro extra auditfees gefactureerd voor accountantsverklaringen bij twee emissieprospectussen en een inbrengverklaring' (Punch Graphix).

12 Onbekend is in 2007 de accountantsorganisatie die in de verkorte jaarrekening van Arcadis niet is genoemd. Arcadis 2008 noemt KPMG als accountant. In 2008 ontbreken bij CTAC en bij Koninklijke Reesink op de elektronische versies van de accountantsverklaring de namen van de accountantsorganisaties. Naar onze mening is het ontbreken van de namen van de accountantsorganisaties een teken van verregaande nonchalance en een overtreding van de wettelijke bepalingen. Ons onderzoek is gebaseerd op openbare gegevens. Om die reden rapporteren wij dat de accountantsorganisatie 'onbekend' is. In 2007 was Van Daal de accountant van CTAC en Deloitte van Koninklijke Reesink.

14 BDO en Mazars worden hier niet genoemd vanwege het geringe aantal cliënten bij de onderzochte ondernemingen.

15 Van Schaik (2003b, p. 307) vindt dit geen betrouwbare maatstaf omdat de accountant belang heeft bij het totale honorarium en niet bij de verhouding van de verschillende categorieën.

16 Het verschil met het totaal van tabel 3 $(€ 312.891)$ zijn de niet-gespecificeerde kosten en de kosten van de niet-genoemde accountantsorganisaties van CTAC en Koninklijke Reesink.

$\mathbf{1 7}$ Dit artikel is opgenomen in een special van het International Journal of Auditing over accountantskostenonderzoek in Angelsaksische landen. In die landen is de openbaarmaking van accountantshonoraria in de jaarrekening al langere tijd verplicht.

18 De studies van DeAngelo (1981), DeFond et al. (2002) en Ghosh et al. (2009) zijn overigens niet besproken in Hay et al. (2006). 
Bijlage Onderzochte ondernemingen en het honorarium voor het onderzoek van de jaarrekening

\begin{tabular}{|c|c|c|c|c|}
\hline & \multicolumn{4}{|c|}{$\begin{array}{l}\text { Honoraria voor het onderzoek van de } \\
\text { jaarrekening (*€ } € 1.000 \text { ) (percentage } \\
\text { van de totale accountantskosten); } \\
\text { lege cellen door ontbrekende gegevens }\end{array}$} \\
\hline & \multicolumn{2}{|r|}{2008} & \multicolumn{2}{|r|}{2007} \\
\hline Aalberts Industries & 1.950 & $(100,0)$ & 1.710 & $(100,0)$ \\
\hline Accell Group & 348 & $(77,7)$ & 303 & $(79,3)$ \\
\hline \multicolumn{5}{|l|}{ Acomo (Amsterdam Commodities) } \\
\hline AEGON & 24.000 & $(92,3)$ & 22.000 & $(91,7)$ \\
\hline Ahold & 5.137 & $(99,0)$ & 8.002 & $(96,5)$ \\
\hline Akzo Nobel & 14.300 & $(89,4)$ & 14.200 & $(93,4)$ \\
\hline $\begin{array}{l}\text { AMT Holding (Amsterdam Molecular } \\
\text { Therapeutics) }\end{array}$ & 75 & $(26,8)$ & & \\
\hline Arcadis & 2.200 & $(71,0)$ & 1.800 & $(64,3)$ \\
\hline ASM International & 2.117 & $(68,0)$ & 2.903 & $(75,7)$ \\
\hline ASML & 1.377 & $(70,1)$ & 1.297 & $(75,3)$ \\
\hline Ballast Nedam & 700 & $(46,7)$ & 600 & $(46,2)$ \\
\hline BAM Groep & 3.000 & $(88,2)$ & 2.900 & $(91,3)$ \\
\hline \multicolumn{5}{|l|}{ Batenburg Beheer } \\
\hline BE Semiconductor Industries & 193 & $(81,4)$ & 210 & $(89,4)$ \\
\hline Beter Bed & 148 & $(86,5)$ & 148 & $(89,2)$ \\
\hline BinckBank & 420 & $(76,8)$ & 433 & $(43,8)$ \\
\hline Blue Fox Enterprises & 164 & $(87,7)$ & 154 & $(82,4)$ \\
\hline Boskalis Westminster & 975 & $(96,5)$ & 895 & $(95,3)$ \\
\hline Brill & 124 & $(77,0)$ & 99 & $(72,8)$ \\
\hline Brunel International & 429 & $(70,0)$ & 497 & $(82,6)$ \\
\hline Corio & 810 & $(61,0)$ & 595 & $(67,2)$ \\
\hline Crown Van Gelder & 94 & $(61,0)$ & 91 & $(60,3)$ \\
\hline Crucell & 840 & $(91,8)$ & 904 & $(93,4)$ \\
\hline CSM & 1.300 & $(88,7)$ & 1.219 & $(95,7)$ \\
\hline Ctac & 79 & $(84,9)$ & & \\
\hline DOCdata & 190 & $(100,0)$ & 180 & $(94,7)$ \\
\hline DPA Flex Group & 171 & $(51,4)$ & 169 & $(58,7)$ \\
\hline Draka Holding & 1.600 & $(100,0)$ & 2.600 & $(1,9)$ \\
\hline DSM & 4.700 & $(40,5)$ & 4.600 & $(59,0)$ \\
\hline ERIKS Group & 884 & $(48,2)$ & & \\
\hline Exact & 233 & $(67,3)$ & 241 & $(71,5)$ \\
\hline Fornix BioSciences & 96 & $(41,6)$ & 100 & $(83,3)$ \\
\hline Fugro & 2.023 & $(83,3)$ & 1.824 & $(86,0)$ \\
\hline Gamma Holding & 1.600 & $(66,7)$ & 1.400 & $(66,7)$ \\
\hline Grontmij & 860 & $(66,4)$ & 750 & $(74,2)$ \\
\hline Heijmans & 2.496 & $(62,5)$ & 2.270 & $(57,2)$ \\
\hline
\end{tabular}

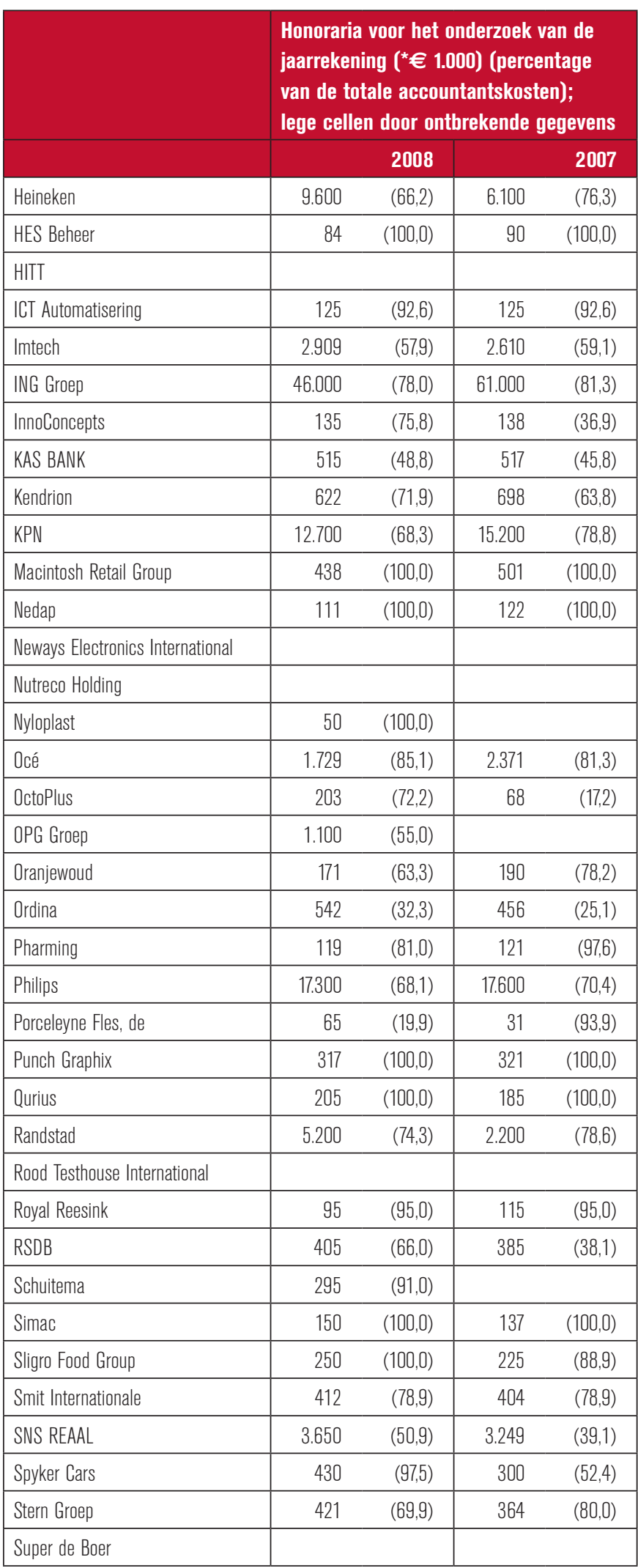


Honoraria voor het onderzoek van de jaarrekening ( $\left.{ }^{*} € 1.000\right)$ (percentage van de totale accountantskosten);

lege cellen door onthrekende gegevens

2008

2007

\begin{tabular}{|l|rc|rc|}
\hline Telegraaf Media Groep (TMG) & 682 & $(78,2)$ & 559 & $(74,2)$ \\
\hline Ten Cate & 801 & $(50,2)$ & 686 & $(43,1)$ \\
\hline TIE Holding & & & & \\
\hline Tiscali & 980 & $(74,7)$ & & \\
\hline TKH Group & 490 & $(99,4)$ & 393 & $(80,5)$ \\
\hline TMC Groep & 100 & $(82,6)$ & 131 & $(86,2)$ \\
\hline TNT & 6.000 & $(66,7)$ & 9.000 & $(69,2)$ \\
\hline TomTom & 791 & $(47,9)$ & 389 & $(45,0)$ \\
\hline Unibail-Rodamco & 3.600 & $(100,0)$ & 4.100 & $(85,4)$ \\
\hline Unilever & 22.000 & $(78,6)$ & 22.000 & $(81,5)$ \\
\hline Unit 4 Agresso & 267 & $(81,7)$ & 282 & $(100,0)$ \\
\hline USG People & 1.832 & $(62,3)$ & 1.612 & $(90,7)$ \\
\hline
\end{tabular}

\begin{tabular}{|c|c|c|c|c|}
\hline & \multicolumn{4}{|c|}{$\begin{array}{l}\text { Honoraria voor het onderzoek van de } \\
\text { jaarrekening ( } € € 1.000 \text { ) (percentage } \\
\text { van de totale accountantskosten); } \\
\text { lege cellen door ontbrekende gegevens }\end{array}$} \\
\hline & \multicolumn{3}{|c|}{2008} & 2007 \\
\hline Value 8 & 22 & $(24,4)$ & & \\
\hline \multicolumn{5}{|l|}{ Van der Moolen } \\
\hline Van Lanschot & 1.133 & $(64,2)$ & 1.348 & $(74,1)$ \\
\hline \multicolumn{5}{|l|}{ VastNed Retail } \\
\hline \multicolumn{5}{|c|}{ Vivenda Media Groep } \\
\hline Vopak & 1.100 & $(78,6)$ & 1.100 & $(68,8)$ \\
\hline Wavin & 930 & $(33,1)$ & 1.060 & $(35,6)$ \\
\hline Wegener & 740 & $(55,8)$ & 883 & $(56,6)$ \\
\hline Wereldhave & 447 & $(84,0)$ & 451 & $(83,8)$ \\
\hline Wessanen & 1.500 & $(88,2)$ & 1.500 & $(83,3)$ \\
\hline Wolters Kluwer & 3.800 & $(60,3)$ & 4.200 & $(60,9)$ \\
\hline
\end{tabular}

$30284^{\circledR}$ JAARGANG JUNI 